\title{
The Main Technical-Economic Aspects of the Fruit Market at Research and Development Station for Fruit Growing Iași
}

\author{
Elena LEONTE, Aurel CHIRAN, George UNGUREANU, Maria ROBU*, Alexandru Marcel FRONEA \\ Faculty of Agriculture, "Ion Ionescu de la Brad" University of Agricultural Sciences and Veterinary \\ Medicine Iași, 3 Mihail Sadoveanu Alley, 700490 Iași, Romania \\ *corresponding author: maria.bogus@yahoo.com
}

BulletinUASVM Horticulture 77(1) / 2020

Print ISSN 1843-5254, Electronic ISSN 1843-5394

DOI:10.15835/buasvmcn-hort: 2019.0022

\begin{abstract}
The Romanian fruit market has a high growth potential but, to a great degree, after 1989 it has registered a reverse phenomenon. The fruit estate, consisting of orchards and nurseries, totaled in the 80 s around 290.000 ha, representing $2 \%$ of the agricultural area of the country. Nowadays, the fruit heritage is a lot diminished. In 2010, Romania had 196,000 hectares of orchards, these surfaces decreasing by 2016 when they totaled 138,000 hectares, representing 1\% of the agricultural area of the country. For the recovery of this sector, it is necessary to renew the fruit plantations. Also, the range of fruit products needs to be diversified so that Romania can enter the European markets. In addition, Romanian producers should be encouraged by introducing tax exemptions and by granting new types of subsidies. In this way, Romania will be able to become competitive on the European and global market. The studies carried out on Research and Development Station for Fruit Growing (RDSFG) Iasi show how using high performance hybrids, as well as widening the range of products and maintaining a distribution process with no intermediaries have helped the company preserving a significant market share and increasing its turnover in the last years.
\end{abstract}

Keywords: fruits, market, orchards, policies

\section{Introduction}

With a world population predicted to reach eight billion by the year 2030 and almost ten billion in 2050 (United Nations Department of Economic and Social Affairs, 2015) the demand for food would increase considerably. Providing important nutritive elements for people living in both developed and developing countries, fruits and vegetables will play an essential role in the daily nutritional plan. In developed countries, the U.S. continues to dominate the international trade of fruits and vegetables, and is ranked number one as both importer and exporter, accounting for approximately $18 \%$ of the $\$ 40$ billion (USD) in fresh produce world trade according to the Global Agricultural Trade System (GATS), USDA's Foreign Agricultural Service (www.fas.usda.gov).

Being an important sector for a region's economy and development, horticulture represents more and more a branch of interest for developing countries also. In the last years it has been noticed a growth in horticultural exports from developing countries, Latin-America more than tripled in the past 20 years its horticultural 
exports and Africa and Asia more than quadrupled (Van den Broeck and Maertens, 2016). In this regard, the development and modernization of the horticultural sector as an export diversification and poverty reduction strategy became a priority for governments around the globe. Experts consider that horticultural exports have the pontential to lead to a poverty reduction due to the use of low-skilled labor in production and post-harvest activities, and the high intrinsic value of produce (Aksoy and Beghin, 2005).

For the European Union (EU) fruit and vegetables market is also an important segment, its annual output being valued at over $€ 57$ billion in 2018, of which about $60 \%$ is accounted for by vegetables and nearly $40 \%$ by fruit. The sector's output represents one quarter of the value of the EU's total crop output and $14 \%$ of the overall agricultural output value, with a $30 \%$ increase in ten years (Eurostat, 2018). Therefore, the fruit market, in general, is characterized by an increase of the cultivated areas yearly, especially of the intensive cultivation systems. Countries such as Spain, Italy and Poland are leaders in the fruit production sector. Spain is the European leader in orange production (with $54 \%$ of the total crop production in EU), with high shares in peach crop production also $35 \%$ of the total crop production in EU) and with a lower percent in pear production (15\% of the total crop production in EU). Italy also registers high shares in fruit production in comparison with other EU countries, registering the highest share of pear crop production in EU with $31 \%, 26 \%$ of the total oranges crop production in EU and 19\% of the total apple crop production in EU. Romania registers low fruit crop productions, with under $10 \%$ in apple, pear and peach crop production in EU (Eurostat, Crop production in EU standard humidity, 2018).

The Romanian fruit market has a high growth potential, the climate and soil offering favorable conditions for the cultivation of a widespread species of fruit trees, depending on their biological requirements they can grow throughout the country from plain to altitudes above 800-1000 $m$ (MARD, 2007). After the fall of the communism, the relocation of nationalized lands to the former owners began, thus a large part of the Romanian fruit surfaces have been divided in order to be restitute to the former owners, because the communist regime nationalized their properties.
Thereby, many of the new owners either disforested their orchards in order to build buildings or they changed the destination of the lands. The fruit estate, consisting of orchards and nurseries, totaled in the 80 s around 290.000 ha, representing $2 \%$ of the agricultural area of the country. Nowadays, the fruit heritage is a lot diminished. In 2010, Romania had 196.000 hectares of orchards, these surfaces decreasing by 2016 when they totalized 138.000 hectares, representing $1 \%$ of the agricultural area of the country (INS, 2016).

One of the main structural limits of the Romanian fruit sector is the small size of agricultural units. In Romania only $1.5 \%$ of the total agricultural holdings are represented by large, industrialized and performing farms, being registered in total over 3.5 million subsistence and semi-subsistence farms. With $91.8 \%$ of the agricultural holdings with an area of less than 5 hectares, Romania faces a paradox: the smallest ratio between the number of agricultural holdings and production. Most agricultural holdings are facing problems in terms of capitalization of production, the lack of effective marketing strategies mirroring in the low income recorded. Even at the European Union level, in 2007, over $70 \%$ of the fruit and vegetable farms did not reach an area of 5 ha. This causes higher costs for farmers, not allowing to reach an efficient production scale and poses limits on competitiveness in the world market. In the European Union, apples have been for years the main fruit produced "both in terms of output value (about one fifth of overall fruit production) and volume of harvested production (29\% of total fruit production)" (The EU fruit and vegetables sector: overview and post 2013 CAP perspective, Agricultural and Rural Development, European Parliament). Romanian apple plantations, for the most part, are in decline, many apple orchards being older than 25 years with a low productive potential, other orchards are declining or abandoned, while a concrete strategy for the development of this sector is delayed.

Even though EU has a large potential of being an important supplier of fruits and vegetables, its production is seasonal and limited by its climate. In order to cover its population's demand of highquality fresh fruits and vegetables year-round, EU must import.

When analyzing the fruit market, we must consider four essential elements: market demand 
and supply, distribution, prices and consumption according to Chiran et al. (2003). The fruit offer is provided by the agricultural producers, the food industry companies that have their own shops where they value their production, wholesalers, and retailers. In cities, an important role is played by hypermarkets which offers a wide range of fruits to consumers.

Within a market economy, it is the fruit demand that imposes what sortiments should be produced and in what quantities. The demand of fruits in a country is directly influenced by the population's food system, as well as by their purchasing power. Normally, the supply of fruit must match, in terms of volume and structure, with the demand, while the supply surplus should be export oriented.

The distribution of fruits is a more special problem because the direct route from the producer to consumer has to be realized in the shortest time so that the fruits do not lose their specific characteristics. The following types of distribution are found in the fruit market, according to Jugănaru (1997):

- direct distribution: which is a classic form of distribution, which implies a direct route between the producer and the consumer, being also known as "trade at the stalls", which is practiced most often by the private producers.

- short channel distribution: (producer - intermediary - consumer), it is common among market speculators.

- distribution through long channel: (assumes the presence of at least two intermediaries), it is characteristic for the most important fruit producing countries.

- distribution through wholesale markets: (at least three intermediaries) is a distribution with a long channel, its purpose being to provide large cities with a sufficient amount of fruit.

Due to the influence of climatic conditions, fruit production may undergo changes which will be reflected in its prices. Hence, not only the demand on the market influences the price of fruit but also other factors.

At the macro-economic level the supply of food is determined by food production within a country's boundaries, food stock levels and net food imports (Wu Huang, 2004). It is considered that horticultural exports can increase a country's possibility of importing food and provide better foreign exchange earnings and trade balance.
These aspects positively contribute to a country's economy.

The fruit consumption plays an important role in the daily nutrition of the population. The World Health Organization recommends a fruit consumption of about $200 \mathrm{~g} /$ day.

The most important aspects of the fruit market are related to the following, as stated by Istudor (1996):

- the existence of a varied product range, which differs from one geographical area to another;

- accentuated seasonality regarding the offer;

- the sale availability for products made after the passing of the fresh fruit season;

- poor organization in terms of selling;

- high share of self-consumption;

- limited spaces for fruits storing and preservation.

In 2017, the area of orchards in Europe was about 1.3 million hectares, of which over a third were cultivated with apples $(473,500$ ha $-37 \%)$, while oranges represented $20 \%(255,500 \mathrm{ha})$. The plantations of peaches represented 15\% $(190,500$ ha), those of clementines $11 \%(139,600$ ha), the pears owned $8 \%(100,400$ ha), those of apricots $6 \%(75,700 \mathrm{ha})$, and those of lemons $5 \%(60,100$ ha).

Romania's fruit estate (orchards and nurseries) represented 290.000 hectares in the $80 \mathrm{~s}$ while in 2016 it summed only 138.000 hectares. Since 1990, the fruit sector has deteriorated from year to year. Because around the big cities, there were large fruit plantations, they were cleared in order to develop the real estate sector, this being especially visible in Bucharest.

The area with orchards of Europe represented in 2017 only 1\% of the agricultural area of the continent which is 173 million hectares. Two thirds of this area is concentrated in Spain, Italy and Poland. Spain occupies the first place in 2017 with an area of 422,800 ha (33\%), followed by Italy with 279,300 ha $(22 \%)$ and Poland with 167,300 ha $(13 \%)$.

Another factor that led to the weakening of this sector is the fact that after decollectivization, small portions of the fruit estate have come into the possession of the former owners, who either did not take care of them or deforested them.

The analysis carried out in Iasi county mirrors a situation on the local fruit market, having a specific research unit from the branch as a 


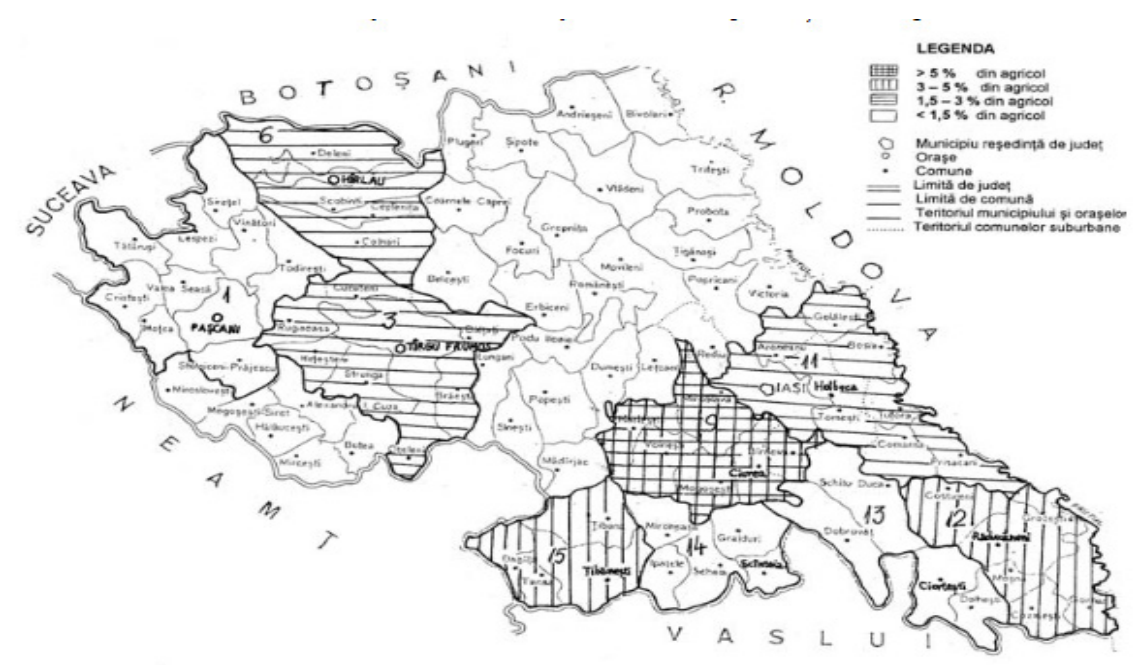

Figure 1. The main orchard areas situated in Iasi County, Romania Source NIS, 2010

reference. All the quantitative and financial data of this unit were analyzed for the last years.

Through the present paper, we will outline a series of factors which contributed in weakening the Romanian fruit sector, together with analyzing the evolution of the most important units which trade fruits, located in Iasi County, one of the most developing regions of Europe.

\section{Materials and methods}

The necessary studies for the elaboration of the present paper were carried out during the years 2018 - 2019, using primary data as the main source of information. The research from primary data were obtained with the help of a series of in-depth interviews applied on a fruit producer located in Iasi County, Romania. In this regard, a series of interviews took place at the headquarters of the agricultural unit under study, in the RDSFG Iași. The respondents were representatives of the agricultural enterprise, with power of decision (director, managers). The duration of the interviews ranged from 20 to 45 minutes, a series of specific documents of the company being analyzed and discussed, such as: the evolution of the crop areas, the financial accounting documents regarding the evolution of the economic indicators, the evolution of the technical capacity in terms of the investments. The data obtained through these in-depth interviews were interpreted in order to highlight the fruit production opportunities in Iasi County, Romania, as well as the needs and problems encountered by the agricultural producers.

On the other hand, data from secondary sources, respectively Romanian and foreign specialized literature and studies have been used, available and applicable at international level. Both the data obtained from the analysis of agricultural unit documents and those from the specific literature have been processed and interpreted in order to highlight the development of the studied unit.

\section{Results and discussions}

In Romania, the yields per hectare are below the EU-28 average. In addition, Romanian producers were powerless in the face of the large wave of imports as well as the lack of regulations to ease their entry to the market (Chiran et. al., 2007). An example of an appropriate measure for them would be to encourage local consumption of fruits and vegetables. In addition, the state should encourage the formation of producer associations for the added value of the products to increase, and thus the Romanian fruits can become competitive on other markets as well. Also, launching marketing and management courses of fruit farms and various specialized courses for owners can make them more aware of market trends and needs.

The fruit consumption in the region is decreasing, in 2015, in the North-Eastern region an average of $4.15 \mathrm{~kg}$ fruits/month was consumed 
Table 1. The evolution of the fruit plantation surfaces 2010-2016 timeframe

\begin{tabular}{ccccccccc}
\hline Specification & MU & 2010 & 2011 & 2012 & 2013 & 2014 & 2015 & 2016 \\
\hline Surface & $\begin{array}{c}\text { thousands } \\
\text { of hectares }\end{array}$ & 198,6 & 140,0 & 142,2 & 144,1 & 140,8 & 138,5 & 138,0 \\
\hline
\end{tabular}

Source: NIS, 2010-2016

Table 2. Fruit plantations of Romania in 2017

\begin{tabular}{cc}
\hline Structure of plantations by species & Surface (ha) \\
\hline Apple & 55.050 \\
\hline Pears & 3.231 \\
\hline Apricot & 2.361 \\
\hline Peach & 1.693 \\
\hline Plum & 65.100 \\
\hline Cherry and sour cherry & 6.127 \\
\hline Nectarine & 152 \\
\hline Nuts & 1.670 \\
\hline
\end{tabular}

Source: NIS, 2017

per inhabitant (49.8 $\mathrm{kg} /$ year), in 2017 the consume diminished to only $4.06 \mathrm{~kg}$ fruits $/$ month/ inhabitant $(48.7 \mathrm{~kg} /$ year), data provided by the National Institute of Statistics (INS, 2017). As the general fruit consumption and the purchasing power is low, most of the fruit production is directed to the processing or export sector, as is the case of Cerasus Group, which exports fruits to Russia. The biggest opportunity for the small producers is to join larger groups of producers, in order to access European funds more easily and to obtain a better price for their products.

The Iasi fruit market can also be developed if the production of cherries and sour cherries will rise, given the recent evolution of prices. In 2010, in Iasi county were occupied about 2600 hectares with cherry and sour cherry trees. Therefore, we can see a growth potential in this sector, since more than one third of the county is occupied with orchards (Fig. 1).

Regarding the distribution system, the most common one in Iași County is the direct distribution, the merchants selling their products in markets and fairs. In addition to the direct one, there is also a short channel distribution, in which speculators appear. With organized and informed producers, with a well-developed distribution, and with a long-term strategy to encourage this sector, fruit-growing could develop harmoniously, both in the county and local level (Ungureanu,
Table 3. Fruit production by species in 2017

\begin{tabular}{cc}
\hline Species & Quantity (tons) \\
\hline Plums & 444.922 \\
\hline Apples & 348.656 \\
\hline Pears & 48.878 \\
\hline Peaches & 18.546 \\
\hline Nectarines & 794 \\
\hline Cherries and sour cherries & 58.474 \\
\hline Apricots & 33.851 \\
\hline Nuts & 45.797 \\
\hline Strawberries & 27.050 \\
\hline Other fruits & 31.526 \\
\hline
\end{tabular}

Source: NIS, 2017

2012). Compared to 2010, the area of fruit trees has decreased from 198.6 thousand hectares to 138 thousand hectares at present (Tab. 1).

As can be seen from this table, the fruit sector is in a major decline. According to the data provided by the Ministry of Agriculture and Rural Development, the fruit-growing area represents $1.2 \%$ of the agricultural cultivated area. Also, the diminishing tendency of these areas is maintained, the deforestations during the 2008-2012 period being 5,722 ha, while the newly established areas were only 3,007 ha. In addition, only $7 \%$ of the total area of fruit trees is represented by young plantations, while yielding orchards occupy 67,110 .

The structure of the orchard surfaces by species can be seen in Table 2 .

Romania has an extensive production of apples, plums, cherries and sour cherries. The total fruit production in Romania is presented in Table 3.

As observed in Table 3 the production of plums and apples cumulated represents $77 \%$ of Romania's fruit production. Most of the yield is used for natural juice production, this segment occupying $70 \%$ of the market.

Although Iasi county has all the pedoclimatic conditions favorable for the cultivation of fruit trees, being in the first place within the first eight counties of the North-Eastern region of Romania, 
Table 4. Orchard areas in Iași county in 2010

\begin{tabular}{cccccccccc}
\hline County & \multicolumn{1}{c}{ Fruit trees } & \multicolumn{2}{c}{ Nurseries } \\
\hline Iași & Apples & Peaches & Plums & Apricots & $\begin{array}{c}\text { Peaches and } \\
\text { nectarines }\end{array}$ & $\begin{array}{c}\text { Cherries and } \\
\text { sour cherries }\end{array}$ & Quinces & $\begin{array}{c}\text { Other fruit } \\
\text { trees }\end{array}$ & \\
\hline Total ha & 3164 & 736 & 3278 & 408 & 102 & 2596 & 202 & 472 & 77 \\
\hline
\end{tabular}

Source: The County Statistics Department

Table 5. Evolution of the turnover of RDSFG Iasi in 2016-2018

\begin{tabular}{ccc}
\hline \multicolumn{3}{c}{ Net turnover (lei) } \\
\hline 2016 & 2017 & 2018 \\
\hline 4.120 .583 & 4.244 .322 & 5.443 .965 \\
\hline
\end{tabular}

Source: RDSFG Iasi financial data

the fruit production is the same as throughout the country (RDSFG Iași, 2012).

In 2010, the fruit area of Iasi County was 11,045 ha, the largest surface being occupied by plums and apples while the nurseries occupy a small area in comparison with the total orchard surface (Tab. 4).

Regarding the RDSFG Iasi economical activity, a series of elements are influencing it on the Romanian market: the fruit demand, the offer and the prices established by its main competitors. In order to increase the volume of sales, maintaining in the same time the "qualityprice" ratio in favor of the customers, RDSFG Iasi focused on using high performance hybrids as well as widening the range of products. RDSFG Iasi supplies a large part of its production to fresh consumption. There are not many intermediaries in the distribution process, most of it is directly performed because the unit has a warehouse with a capacity of 5,500 tons where the sales process is realized. In analyzing the economic results of the company, an important role is played by the turnover. The turnover obtained by RDSFG Iasi

Table 6. The first five companies activating in fruit sector in Iasi county, according to their turnover in 2018

\begin{tabular}{ccc}
\hline No & Company & $\begin{array}{c}\text { Turnover } \\
\text { obtained (mil lei) }\end{array}$ \\
\hline 1 & S.C. MALY FRUITS S.R.L. & 8,3 \\
\hline 2 & S.E. CITRO IMPEX S.R.L. & 7,4 \\
\hline 3 & S.C. BANAFRESH S.R.L. & 6,9 \\
\hline 4 & S.C. CERASUS GRUP S.R.L. & 6,1 \\
\hline 5 & RDSFG Iasi & 5,4 \\
\hline 6 & Other companies & 11,3 \\
\hline 7 & TOTAL & 45.4 \\
\hline
\end{tabular}

Source: Ministry of Public Finance (www.mfinante.ro)

during the period 2016-2018 had the following evolution (Tab. 5).

According to Table 5, the turnover of RDSFG Iasi had a relatively equal value between 2016 and 2017, the increase being more evident in 2018. The turnover in 2018, respectively 5,443,965 lei is $32.1 \%$ higher than the one obtained in 2016. The fact that between 2016 and 2017 it remained relatively equal, it shows that customers have greater confidence in RDSFG Iasi products and services. The increase in 2018 is due to a high apple production. In Iași county, there are numerous companies dealing with the activity of "wholesale of fruits and vegetables" precisely 43 economic agents that carry out this activity and the total turnover is 45.4 million lei. The first five companies with this field of activity registered a total turnover of 34.1 million lei, which means that the market has a high degree of concentration (Ministry of Public Finance, 2018). In 2018, the first five companies in Iași county that had as an object of activity "wholesale of fruits and vegetables" obtained the following turnover (Tab. 6). 


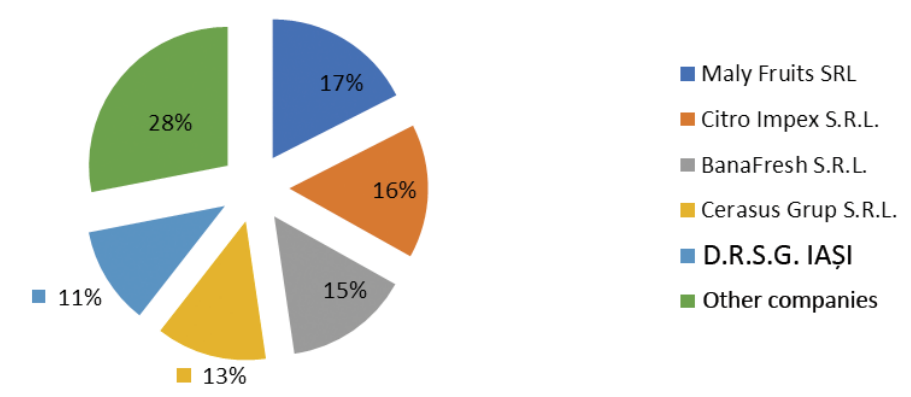

Figure 2. Market shares in fruit sector registered in Iasi county in 2018 Source: Ministry of Public Finance (www.mfinante.ro)

These five companies obtained the specific market shares presented in Figure 2.

RDSFG Iasi is the fifth company according to its market share (Fig. 2) in Iasi county, and occupies the same place regarding its turnover (Tab. 6).

\section{Conclusions}

There has been noticed a substantial growth in the volume and variety of fruits and vegetables traded globally. Three regions - the European Union (EU), the North American Free Trade Agreement (NAFTA) area, and Asia (East, Southeast, and South) are the major destinations, as well as the major sources of supply, for this trade. These major trading patterns exist for a variety of reasons, such as: demand, climate, location, technology, costs, factor endowments, infrastructure, incomes (Wu Huang, 2004). High-income countries like the United States, EU members, Japan, and Canada, account for the overwhelming majority of the fruit and vegetable trade, as well as for its growth. The EU and the United States, in particular, are the largest traders in the global market of fruits and vegetables.

Globalization of the fruit and vegetable trade has made fresh products accessible to consumers around the world, overcoming seasonality and smoothing price fluctuations.

Developed countries dominate global consumption and trade of fruits and vegetables, not only because of their high income levels but also because of consumers' increasing concerns about healthy eating and variety (Segre, 1998). Whereas, in developing countries horticulture is a sector that can help revive the economy, offering jobs and balancing the trade.

Although Romania is a developing country, a special attention to its horticultural productivity should be paid, since 1990 this sector has deteriorated from year to year. Even if the Romanian fruit market has a high growth potential, the climate and soil offering favorable conditions for the cultivation of a widespread species of fruit trees, the Romanian fruit productions diminished in the past years.

In addition, Romanian producers were powerless in the face of the large wave of imports as well as the lack of regulations to ease their entry to the market. An example of an appropriate measure for them would be to encourage local consumption of fruits and vegetables. In addition, the state should encourage the formation of producer associations for the added value of the products to increase, and thus the Romanian fruits can become competitive on other markets as well. Also, launching marketing and management courses of fruit farms and also various specialized courses for owners of fruit farms, can make them more aware of market trends and needs.

However, even in these conditions, a series of companies which manage to apply efficient marketing strategies succeed in their objective of delivering high quality products on the market at low prices in comparison with more developed countries. This is the case of RDSFG Iasi, the fifth company in the fruit sector in Iasi county, Romania, according to its market share and turnover in 2018. The company reached in 2018 a turnover higher with more than one million lei in comparison with 2016, due to a price strategy shaped on its target audience power of buying and to fruit production share. After two years of constant financial losses, the company managed to redress and to became a brand on the local market due to the applied product strategies: launching new hybrid varieties according to the market demand. 
Acknowledgments: This work was supported by a grant of the Romanian Ministry for Research and Innovation, CCDI - UEFISCDI, project number PN-III-P1-1.2-PCCDI-2017-0850/ contract 14 PCCDI /2018 within PNCDI III.

\section{References}

1. Aksoy MA, Beghin JC (2005). Global agricultural trade and developing countries, Washington DC: The World Bank.

2. Chiran A, Dima FM, Gindu E (2007). Marketing în agricultură, Alma Print Galați Publishing House, p. 55, pp. 56-58, p. 83, Galați.

3. Chiran A, Gîndu E, Banu A, Ciobotaru EA (2003). Marketing Agroalimentar Teorie și Practică, Ion Ionescu de la Brad Publishing House, Iași.

4. Eurostat (2018). Crop production in EU standard humidity.

5. Global Agricultural Trade System (GATS) (2019). USDA's Foreign Agricultural Service (www.fas.usda.gov).

6. Istudor N (1996). Marketingul legumelor și fructelor, Rev Tribuna Economică București, 1-5.

7. Jugănaru M (1997). Construirea mixului de marketing, Rev. Management-Marketing București, 3-4.

8. MADR (Ministry of Agriculture and Rural Development), Direcția Generală Politici Agricole și Strategii (2007). Strategia națională pentru programele operaționale în sectorul de fructe și legume, Perioada 2018-2020 http://www.madr.ro/docs/agricultura/legume-fructe/ strategie-legume-fructe-2018-2020.pdf.

9. Ministry of Public Finance (2016-2018), www.mfinante. ro.

10. National Institute of Statistics (NIS) (2010-2018). Recensământul agricol.

11. Segre A (1998). Global horticultural impact: Fruits and vegetables in developing countries, World Conference on Horticultural Research, Rome, Italy, June 17-20.

12. RDSFG (Research and Development Station for Fruit Growing) Iași (2012). Cercetare, inovare și progres în pomicultura ieșeană, Editura ALTFEL, Iași.

13. The EU fruit and vegetables sector: overview and post 2013 CAP perspective (2011), Agricultural and Rural Development, European Parliament, http:// www.europarl. europa.eu/RegData/etudes/etudes/ join/2011/460043/IPOL-AGRI_ET(2011)460043_EN.pdf

14. Ungureanu G (2012) Managementul producției agricole, ediția a II-a revizuită, Editura TipoMoldova, Iași.

15. United Nations Department of Economic and Social Affairs, Population Division, World Population prospects: The 2015 Revision, by United Nations Department of Information https://www.un.org/en/development/ desa/publications/world-population-prospects-2015revision.html.

16. Van den Broeck G, Maertens M (2016). Horticultural exports and food security in developing countries. Global Food Security.

17. Wu Huang S (2004). Agriculture and Trade Report, Research Service/USDA. 